\title{
Faktor-Faktor yang Berhubungan dengan Bronkiolitis Akut
}

\author{
Ida Bagus Subanada, ${ }^{*}$ Darmawan B Setyanto, ${ }^{* *}$ Bambang Supriyatno, ** \\ Imam Boediman** \\ *Bagian/SMF Ilmu Kesehatan Anak FK UNUD-RSUP Sanglah, Denpasar \\ **Departemen Ilmu Kesehatan Anak FKUI-RSCM, Jakarta
}

Latar belakang. Terdapat beberapa faktor yang mempengaruhi terjadinya bronkiolitis akut. Seperti halnya usia, jenis kelamin, lahir kurang bulan, berat lahir rendah, jumlah keluarga serumah, status gizi, air susu ibu (ASI), paparan asap rokok, riwayat atopi, dan imunisasi BCG.

Tujuan. Untuk mengetahui hubungan antara ASI, paparan asap rokok, riwayat atopi, dan BCG dengan bronkiolitis akut.

Metode. Desain potong lintang, data didapat dari rekam medis pasien yang dirawat. Analisis data dengan metode univariat dan multivariat, tingkat kemaknaan $\alpha=0,05$ (IK95\%).

Hasil. ASI dan paparan asap rokok tidak berhubungan dengan bronkiolitis akut, sedangkan riwayat atopi pada orangtua, parut BCG, dan jenis kelamin berhubungan dengan bronkiolitis akut $\{\mathrm{RP} 20,41$ (IK95\% 1,09;333,33), $p=0,043$, RP 0,23 (IK95\% 0,07; 0,79), $p=0,019$, dan RP 3,42 (IK95\% 1,10;10,64), p=0,034)\}.

Kesimpulan. Riwayat atopi pada orangtua, parut BCG, dan jenis kelamin berhubungan dengan bronkiolitis akut. (Sari Pediatri 2009;10(6):392-6).

Kata kunci: ASI, asap rokok, riwayat atopi, BCG, bronkiolitis

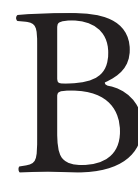
ronkiolitis akut adalah peradangan pada bronkiolus yang ditandai oleh sesak napas, mengi, dan hiperinflasi paru. ${ }^{1}$ Penyakit bronkiolitis akut merupakan infeksi respiratorik akut bagian bawah (IRA-B) yang sering pada bayi. Sekitar 20\% anak pernah mengalami satu episode IRA-B dengan mengi pada tahun pertama. ${ }^{2}$

\section{Alamat Korespondensi:}

Dr. Ida Bagus Subanada, Sp.A. Divisi Respirologi Bagian/SMF IKA FK Unud/RSUP Sanglah Denpasar, e-mail: subanada@yahoo.com, HP: 08123995933.
Angka kejadian rawat inap IRA-B tiap tahun berkisar antara $3000^{3-5}$ sampai 50.000-80.000 bayi, ${ }^{6}$ kematian sekitar 2 per- 100.000 bayi. ${ }^{3,7}$ Bronkiolitis akut bersifat musiman, pada umumnya terjadi pada usia kurang dari 2 tahun dengan puncak kejadian pada usia 6 bulan pertama, ${ }^{8,9}$ serta lebih sering pada laki-laki. ${ }^{6,9}$

Pasien bronkiolitis akut berat mempunyai risiko mengalami mengi berulang atau asma. ${ }^{10-12}$ Belum jelas apakah predisposisi untuk menjadi asma juga merupakan faktor risiko untuk menjadi bronkiolitis atau apakah infeksi virus terlibat dalam munculnya asma. ${ }^{10,13-15}$ Beberapa penelitian mendapatkan hubungan antara asma pada first degree relative dengan 
bronkiolitis akut berat pada usia dini. ${ }^{16-18}$ Penelitian lainnya mendapatkan bahwa air susu ibu (ASI) mempunyai efek proteksi, ${ }^{19-21}$ sedangkan paparan asap rokok merupakan faktor risiko IRA-B. ${ }^{22-25}$ Penelitian tentang vaksinasi BCG dikatakan dapat mengurangi kejadian mengi. ${ }^{26} \mathrm{Di}$ samping itu terdapat beberapa faktor lain yang diduga berhubungan dengan bronkiolitis akut antara lain faktor mekanis (diameter saluran napas) dan kepadatan rumah (jumlah keluarga serumah) ${ }^{6,9}$ Atas dasar latar belakang tersebut maka penelitian dilakukan dengan tujuan mencari hubungan antara ASI, paparan asap rokok, riwayat atopi, dan vaksinasi BCG dengan bronkiolitis akut.

\section{Metode}

Penelitian potong lintang dilakukan di Divisi Respirologi Departemen Ilmu Kesehatan Anak FKUIRSCM Jakarta pada bulan Mei 2007. Subjek dipilih secara consecutive sampling, dihitung dengan rule of thumb terhadap empat luaran yang akan dicari yaitu ASI, paparan asap rokok, atopi, dan BCG sehingga diperlukan 80 subjek. Pasien dengan rekam medis yang tidak lengkap tidak diikutsertakan dalam penelitian.

Data didapat dari buku register pasien rawat jalan dan rawat inap. Sebagai kontrol diambil dari pasien yang tidak menderita bronkiolitis akut pada periode yang sama.

Definisi operasional variabel: bronkiolitis akut, bila dari rekam medis terdiagnosis bronkiolitis akut oleh dokter; usia kehamilan dibagi menjadi kurang bulan ( $<37$ minggu), cukup bulan (37-42 minggu), lebih bulan ( $>42$ minggu; vaksinasi BCG: dikatakan ya apabila dijumpai parut BCG, berat lahir dibagi menjadi tiga yaitu $<2.500 \mathrm{~g}, 2.500-4000 \mathrm{~g},>4.000 \mathrm{~g}$; pemberian ASI apakah ASI eksklusif, bila hanya ASI diberikan sampai usia 6 bulan atau sesuai usia pasien (bila usia pasien belum 6 bulan), status gizi yaitu gizi kurang apabila berat badan (BB) terhadap umur berdasarkan jenis kelamin berada < persentil 3 grafik NCHS, gizi normal apabila BB terhadap umur berdasarkan jenis kelamin terletak antara persentil 3-97 NCHS, dan gizi lebih apabila $\mathrm{BB}$ terhadap umur berdasarkan jenis kelamin terletak > persentil 97 NCHS; paparan asap rokok dikatakan terpapar asap rokok apabila di dalam rumah ada orang yang merokok, orangtua menderita atopi bila salah satu atau kedua orangtua menderita atopi antara lain berupa dermatitis atopi, rinitis alergika, alergi makanan, konjungtivitis alergika, asma, atau urtikaria; jumlah keluarga serumah dibagi menjadi $<4$ orang/rumah dan $\geq 4$ orang/rumah. Data yang diperoleh disajikan dalam bentuk narasi dan tabel, dianalisis dengan uji kai-kuadrat atau uji mutlak Fisher, dan analisis multivariat (regresi logistik) dengan menggunakan SPSS dengan tingkat kemaknaan $\alpha=$ 0,05 (IK95\%).

\section{Hasil}

Dari 104 anak dalam data rekam medik, 24 subjek tidak diikutsertakan dalam penelitian karena catatan medik tidak lengkap. Rerata umur subjek 9,3 (SB 6,33 ) bulan, laki-laki 55\%, kehamilan kurang bulan $70 \%$, berat lahir $<2.500$ gram $12,5 \%$, gizi lebih/obese $10 \%$, dan penghuni rumah $\geq 4$ orang $22,5 \%$. Dari kelompok yang tidak menderita bronkiolitis akut, 24 anak didiagnosis pneumonia, 15 anak menderita gizi kurang, 12 anak menderita tuberkolosis; sindrom Down, dan defek septum ventrikel masing-masing 5 orang; gagal tumbuh 4, trakeomalasia 3, defek setum atrium 2, palsi serebral, atresia ani, penyakit Hirschsprung, dan rinobronkitis masing-masing seorang. Untuk kelompok yang menderita bronkiolitis akut, gizi kurang didapat pada 8 orang; defek septum ventrikel dan tonsilofaringitis akut masing-masing 3 orang; hernia skrotalis, gagal tumbuh, dan defek septum atrium masing-masing 2 orang; retinopati pada bayi kurang bulan, dermatitis atopik, dan rinitis alergika masing-masing seorang. Beberapa subjek pada kedua kelompok ada yang menderita lebih dari satu penyakit. Karakteristik subjek pada kedua kelompok tertera pada Tabel 1.

Dari analisis univariat tidak didapatkan hubungan yang bermakna secara statistik antara ASI, dan paparan rokok baik paparan rokok bersumber dari ayah maupun dari ibu dengan kejadian bronkiolitis akut. Imunisasi BCG dan riwayat atopi dalam keluarga berhubungan dengan kejadian bronkiolitis akut. Riwayat atopi pada ibu mempunyai risiko lebih besar daripada riwayat atopi pada ayah \{RP 1,95 (IK95\% 1,$32 ; 2,88$ ) vs RP 1,78 (IK95\% 1,21;2,63)\}(Tabel 2).

Dari variabel-variabel yang bermakna secara statistik pada Tabel 2 serta ditambah variabel jenis kelamin (Tabel 1), dilakukan analisis multivariat (regresi logistik), ternyata adanya parut BCG, riwayat atopi pada orangtua, dan jenis kelamin laki- 
Ida Bagus Subanada dkk: Faktor-Faktor yang Berhubungan Dengan Bronkiolitis Akut

Tabel 1. Karakteristik subjek

\begin{tabular}{lcc}
\hline \multicolumn{1}{c}{ Karakteristik } & Bronkiolitis ( $\mathrm{n}=40)$ & Bukan bronkiolitis $(\mathrm{n}=40)$ \\
\hline Usia, bulan, rerata (SB) & $9,1(5,68)$ & $9,6(6,99)$ \\
Jenis kelamin, laki, $\mathrm{n}(\%)$ & $26(65)$ & $18(45)$ \\
Usia kehamilan kurang bulan, $\mathrm{n}(\%)$ & $30(75)$ & $26(65)$ \\
Berat lahir $<2,500$ gram, n (\%) & $6(15)$ & $4(10)$ \\
Gizi lebih/obese, $\mathrm{n}(\%)$ & $4(10)$ & $4(10)$ \\
Penghuni rumah $\geq 4$ orang, $\mathrm{n}(\%)$ & $10(25)$ & $8(20)$ \\
\hline
\end{tabular}

Tabel 2. Analisis univariat faktor-faktor yang berhubungan dengan bronkiolitis akut

\begin{tabular}{lcccc}
\hline \multicolumn{1}{c}{ Variabel } & $\begin{array}{c}\text { Bronkiolitis } \\
(\mathrm{n}=40)\end{array}$ & $\begin{array}{c}\text { Bukan bronkiolitis } \\
(\mathrm{n}=40)\end{array}$ & RP (IK 95\%) & $p$ \\
\hline ASI, n (\%) & $19(46,3)$ & $22(53,7)$ & $0,86(0,55 ; 1,34)$ & 0,502 \\
Paparan rokok, n (\%) & $32(53,3)$ & $28(46,7)$ & $1,29(0,82 ; 2,01)$ & 0,302 \\
$\quad$ Ibu, n (\%) & $3(60,0)$ & $2(40,0)$ & $1,27(0,42 ; 3,79)$ & 0,644 \\
Ayah, n (\%) & $29(51,8)$ & $27(48,2)$ & $1,12(0,71 ; 1,77)$ & 0,626 \\
Parut BCG, n (\%) & $22(40,0)$ & $33(60,0)$ & $0,47(0,24 ; 0,91)$ & 0,008 \\
Riwayat atopi, n (\%) & $25(78,1)$ & $7(21,9)$ & $2,50(1,58 ; 3,95)$ & 0,000 \\
Ayah, n (\%) & $13(76,5)$ & $4(23,5)$ & $1,78(1,21 ; 2,63)$ & 0,014 \\
Ibu, n (\%) & $17(77,3)$ & $5(22,7)$ & $1,95(1,32 ; 2,88)$ & 0,003 \\
\hline
\end{tabular}

Tabel 3. Analisis regresi logistik BCG, riwayat atopi dan jenis kelamin dalam hubungannya dengan bronkiolitis akut

\begin{tabular}{lccc}
\hline \multicolumn{1}{c}{ Variabel } & Exp (B) & IK 95\% & $p$ \\
\hline Parut BCG & 0,23 & 0,$07 ; 0,79$ & 0,019 \\
Riwayat atopi pada orangtua & 20,41 & 1,$09 ; 333,33$ & 0,043 \\
Ayah & 2,23 & 0,$23 ; 21,61$ & 0,491 \\
Ibu & 1,63 & 0,$14 ; 19,37$ & 0,698 \\
Jenis kelamin laki-laki & 3,42 & 1,$10 ; 10,64$ & 0,034 \\
\hline
\end{tabular}

laki bermakna secara statistik berhubungan dengan bronkiolitis akut (Tabel 3).

\section{Diskusi}

Bronkiolitis akut merupakan salah satu penyebab utama rawat inap pada bayi. ${ }^{9,27,28}$ Di Amerika Serikat, angka rawat inap meningkat secara dramatis (239\%) dari tahun 1980 ke tahun $1996 .{ }^{3}$ Bronkiolitis akut pada umumnya terjadi pada usia di bawah 2 tahun, ${ }^{8,9}$ pada penelitian kami rerata usia pasien 9,1 (SB 5,68) bulan.

Sebagian besar bronkiolitis akut disebabkan oleh respiratory syncytial virus (RSV). ${ }^{9}$ Sekitar 90\% anak usia di bawah 2 tahun terinfeksi oleh RSV dan sekitar $40 \%$ dari mereka berkembang menjadi IRA-B. ${ }^{27}$
Penyebab lainnya antara lain human metapneumovirus, virus influenza, adenovirus, virus parainfluenza, ${ }^{1,27}$ dan mikoplasma pneumonia. ${ }^{1,6}$ Pada penelitian ini penyebab bronkiolitis tidak diperiksa.

Bronkiolitis akut lebih banyak mengenai anak laki-laki. Hal ini dihubungkan dengan kaliber saluran respiratorik yang relatif lebih sempit pada anak laki-laki dibanding perempuan. ${ }^{6}$ Penelitian kami mendapatkan anak laki-laki lebih banyak dari anak perempuan dengan rasio 1,44:1 dan secara statistik bermakna $\{\mathrm{RP}$ 3,42 (IK95\% 1,10;10,64, $p=0,034\}$.

Air susu ibu (ASI) mempunyai antibodi terhadap RSV termasuk IgG, IgA, IFN- $\gamma$, serta mempunyai aktivitas netralisasi melawan RSV. Pullan dkk, ${ }^{29}$ dalam penelitiannya mendapatkan risiko relatif untuk perawatan infeksi RS $V$ sebesar 2,2 pada anak yang tidak minum ASI. Penelitian Bachrach, ${ }^{30}$ mendapatkan 
Ida Bagus Subanada dkk: Faktor-Faktor yang Berhubungan Dengan Bronkiolitis Akut

bahwa ASI eksklusif selama 4 bulan mengurangi risiko rawat inap oleh karena IRA-B (RR 0,28). Hasil berbeda didapatkan jika dikaitkan dengan asap rokok, yang terdiri dari asap utama dan asap sampingan. Asap rokok antara lain mengandung tar, nikotin, dan poliaromatik hidrokarbon. ${ }^{31}$ Paparan asap rokok baik prenatal maupun pascanatal dapat mempengaruhi morfogenesis paru maupun perkembangan sistem imunologis anak. ${ }^{32}$ Satu penelitian mendapatkan bahwa perokok pasif meningkatkan risiko infeksi RSV dengan rasio odd (RO) $3,87 . .^{33}$ Strachan dan Cook, ${ }^{34}$ melaporkan rasio odd (RO) terinfeksi RSV 1,72 bila ibu merokok. Carroll dkk, ${ }^{35}$ pada penelitian kohort retrospektif mendapatkan RR 1,19 (IK95\% 1,08;1,31) bila ibu perokok. Peneliti lainnya melaporkan prevalensi IRA-A meningkat dari $81,6 \%$ menjadi $95,2 \%$ pada bayi jika hanya ayah yang merokok. ${ }^{36}$ Pada penelitian kami, baik ASI eksklusif maupun paparan asap rokok tidak berhubungan dengan bronkiolitis akut, mungkin karena pada kelompok kontrol terdapat penderita IRA di samping sebab lain yang belum jelas.

Vaksin BCG merupakan salah satu vaksin hidup yang dilemahkan, diduga dapat merangsang produksi IFN- $\gamma \cdot{ }^{37}$ Linehan $\mathrm{dkk},{ }^{26}$ pada penelitian kohort retrospektif melaporkan bahwa imunisasi BCG mengurangi kejadian mengi \{RO 0,68 (IK95\% $0,53 ; 0,87)\}$. Pada penelitian kami didapatkan imunisasi BCG mengurangi kemungkinan menderita bronkiolitis akut sebesar 0,77 \{RP 0,23 (IK95\% 0,07;0,79)\}. Adanya rangsangan pembentukan IFN- $\gamma$ oleh BCG pada awal kehidupan mengakibatkan keseimbangan $T h_{1} / T h_{2}$ (Thelper 1 atau Thelper 2) mengarah ke $T h_{1}{ }^{37}$ walaupun pada usia selanjutnya terjadi rangsangan pembentukan $T h{ }_{2}$ oleh RSV yang merupakan penyebab terbanyak bronkiolitis akut. ${ }^{38-40}$

Atopi merupakan salah satu faktor yang diduga sebagai predisposisi bronkiolitis akut. Hal ini didasari karena pasien bronkiolitis akut berat sering mengalami mengi berulang atau berkembang menjadi asma. ${ }^{10-12}$ Carroll dkk, ${ }^{35}$ mendapatkan peningkatan risiko bronkiolitis akut sebesar 1,52 (IK95\% 1,26;1,87) bila ibu menderita asma. Pada penelitian kami, riwayat atopi pada orangtua secara bermakna (dengan IK95\% yang sangat lebar) berhubungan dengan bronkiolitis akut.

Sebagai penutup disimpulkan bahwa adanya riwayat atopi pada orangtua, adanya parut BCG, dan jenis kelamin laki-laki berhubungan dengan bronkiolitis akut. Diperlukan penelitian lebih lanjut untuk menguji konsistensi hubungan tersebut khususnya BCG.

\section{Daftar Pustaka}

1. Paediatric Society of New Zealand. Best Practice Evidence Based Guideline. Wheeze and chest infection in infants under 1 year 2005 (diakses tanggal 28 April 2008). Diunduh dari URL: http//www.paediatrics.org.nz

2. Margolis P, Gadomski A. Does infants have pneumonia? JAMA 1998; 279:308-13.

3. Shay DK. Bronchiolitis-associated hospitalizations among US children, 1980-1996. JAMA 1999; 282:1440-6.

4. Desphande SA, Northern V. The clinical and health econominc burden of respiratory syncytial virus disease among infants under 2 years of age in a defined geographical area. Arch Dis Child 2003; 88:1065-9.

5. Langley J. Increasing evidence of hospitalization for bronchiolitis among Canadian children, 1980-2000. J Infect Dis 2003; 188:1764-7.

6. Watts KD, Goodman DM. Wheezing in infants: bronchiolitis. Dalam: Kliegman RM, Behrman RE, Jenson HB, Stanton BF, penyunting. Nelson Textbook of Pediatrics. Edisi ke-18. Philadelphia: Saunders; 2007. h. 1773-7.

7. Holman RC. Risk factor for bronchiolitis-associated deaths among infants in the United States. Pediatr Infect Dis J 2003; 22:483-9.

8. El-Radhy AS, Barry W, Patel S. Association of fever and severe clinical course in bronchiolitis. Arch Dis Child 1999; 81:231-4.

9. Wohl MEB. Bronchiolitis. Dalam: Chernick V, Boat TF, Wilmott RW, Bush A, penyunting. Kendig's Disorder of Respiratory Tract in Children. Edisi ke-7. Philadelphia: Saundres; 2006. h. 423-32.

10. Sigurs N, Gustafsson PM, Bjarnason R. Severe respiratory syncytial virus bronchiolitis in infancy and asthma and allergy at age 13. Am J Respir Crit Care Med 2005; 171:137-41.

11. Noble V, Muray M, Webb MS, Alexander J, Swarbrick AS, Milner AD. Respiratory status and allergy nine to 10 years after acute bronchiolitis. Arch Dis Child 1997; 76:315-9.

12. Lemanske RF, Jackson DJ, Gangnon RF. Rhinovirus illness during infancy predict subsequent childhood wheezing. J Allergy Clin Immunol 2005; 116:571-7.

13. Stein RT, Sherrill D, Morgan WJ. Respiratory syncyial virus in early life and risk of wheeze and allergy by age 13 years. Lancet 1999; 354:541-5. 
14. Gern JE. Viral respiratory infection and the link to asthma. Pediatr Infect Dis J 2004; 23 (Suppl 1):38-43.

15. Everard ML. The relationship between respiratory syncytial virus infections and the development of wheezing and asthma in children. Curr Opin Allergy Clin Immunol 2006; 6:56-61.

16. Sigurs N, Bjarnasson R, Sigurbergsson F, Kjellman B. Respiratory syncytial virus bronchiolitis in infancy is an important risk factor for asthma and allergy at age 7. Am J Respur Crit Care Med 2000; 161:1501-7.

17. Trefny P, Stricker T, Baerlocher C, Sennhauser FH. Family history of atopy and clinical course of RSV infection in ambulatory and hospitalized infant. Pediatr Pulmonol 2000; 30:302-6.

18. Larouch CH, Rivard G, Deschesnes F, Goulet R, Turcotte $\mathrm{H}$, Boulet LP. Asthma and airway hyperresponsiveness in adults who required hospital admission for bronchiolitis in early childhood. Respir Med 2000; 94:288-94.

19. Pisacane A. Breastfeeding and acute lower respiratory infection. Acta Paediatrica 1994; 83:714-8.

20. Cesar JA. Impact of breastfeeding on admission for pneumonia during post neonatal period in Brazil: nested case-control study. Br Med J 1999; 318:1316-20.

21. Bachrach VRG, Schwarz E. Bachrach LR. Breastfeeding and the risk of hospitalization for respiratory disease in infancy-A meta-analysis. Arch Pediatr \& Adolesct Med 2003; 157:237-43.

22. Jin C, Rossignol AM. Effects of passive smoking on respiratory illness from birth to age eighteen months in Shanghai, People's Republic of China. J Pediatr 1993; 123:553-8.

23. Gurkan F. The effect of passive smoking on the development of respiratory syncytial virus bronchiolitis. Eur J Epidemiol 2000; 16:465-8.

24. Blizzard L. Parental smoking and infant respiratory infection: How important is not smoking in the same room with baby? Am J Public Health 2003; 93:482-8.

25. Nafstad P. Breastfeeding, maternal smoking and lower respiratory tract infection. Eur Respir J 1996; 9:2623-9.

26. Linehan MF, Frank TL, Hazell ML, Francis HC, Morris JA, Baxter DN, dkk. Is the prevalence of wheeze in children altered by neonatal BCG vaccination? J Allergy Clin Immunol 2007; 119:1079-85.

27. Subcommittee on Diagnosis and Management of Bronchiolitis. Diagnosis and management of bronchiolitis. Pediatrics 2006; 118:1774-93.
28. Pelletier AJ, Mansbach JM, Camargo Jr CA. Direct medical cost of bronchiolitis in the United States. Pediatrics 2006; 118:2418-23.

29. Pullan CR, Toms GL, Martin AJ, Gardner PS, Webb JK, Appleton DR. Breastfeeding and respiratory syncytial virus infection. Br Med J 1980; 281:1034-6.

30. Bachrach VR, Schwarz E, Bachrach LR. Breastfeeding and the risk of hospitalization for respiratory disease in infancy: a meta-analysis. Arch Pediatr Adolesc Med 2003; 157:237-43.

31. Sanchez DD, Rumold R, Gong H. Challenge with environmental tobacco smoke exacerbates allergic airway disease in human beings. J Allergy Clin Immunol 2006; 118:441-6.

32. Davies DE, Wicks J, Powell RM, Puddicombe SM, Holgate ST. Airway remodeling in asthma: New insights. J Allergy Clin Immunol 2003; 111:215-25.

33. McConnochie KM, Roghmann KJ. Breastfeeding and maternal smoking as predictors of wheezing in children age 6 to 10 years. Pediatr Pulmonol 1986; 2:260-8.

34. Strachan DP, Cook DG. Health effect of passive smoking. 1. Parental smoking and lower respiratory illness in infancy and childhood. Thorax 1997; 52:905-14.

35. Carroll KN, Gebretsadik T, Griffin MR, Dupon WD, Mitchel EF, Wu P, dkk. Maternal asthma and maternal smoking are associated with increase risk of bronchiolitis during infancy. Pediatrics 2007; 119:1104-12.

36. Shiva F, Basiri M, Sadeghi B, Padyab M. Effect of passive smoking on common respiratory symptoms in young children. Acta Paediatr 2003; 92:1394-7.

37. Hylkema MN, Timens W, Luinge M, van der Werf N, Hoekstra MO. The effect of Bacillus Camette-Guerin immunization depends on the genetic predisposition to Th2-type responsiveness. Am J Respir Cell Mol Biol 2002; 27:244-9.

38. Roman M, Calhoun WJ, Hinton KL. Respiratory syncytial virus infection in infants is associated with predominant Th-2 like response. Am J Respir Crit Care Med 1997; 156:190-5.

39. Kristjansson S, Bjarnarson SP, Wennergren G. Respiratory syncytial virus and other respiratory viruses during the first 3 months of life promote a local Th-2 like response. J Allergy Clin Immunol 2005; 116:805-11.

40. Kusel MMH, de Klerk NH, Kebadze T, Vohma V, Holt PG, Johnston SL, dkk. Early-life respiratory viral infections, atopic sensitization, and risk of subsequent development of persistent asthma. J Allergy Clin Immunol 2007; 119:1105-10. 